\title{
Studies on $\mathbf{N}$-Acetylneuraminic Acid Aldolase
}

\author{
By J. E. G. BARNETT, D. L. CORINA AND G. RASOOL \\ Department of Physiology and Biochemistry, \\ University of Southampton, Southampton SO9 5NH, U.K.
}

(Received 24 June 1971)

\begin{abstract}
$N$-Acetylneuraminic acid aldolase from Clostridium perfringens was irreversibly inactivated by $1 \mathrm{~mm}$-bromopyruvate with a half-life of $4.2 \mathrm{~min}$ at $\mathrm{pH} 7.2$ and $37^{\circ} \mathrm{C}$. The rate of inactivation was diminished in the presence of pyruvate but not with $N$-acetyl-D-mannosamine, indicating that the inhibitor acted at, or close to, the pyruvate-binding site. The apparent $K_{t}$ for bromopyruvate, calculated from the variation of half-life with inhibitor concentration, was $0.46 \mathrm{mM}$, compared with a competitive $K_{\imath} 3.0 \mathrm{~mm}$ for pyruvate. Incubation of the enzyme with radioactive bromopyruvate gave a radioactive, enzymically inactive, protein in which the bromopyruvate had alkylated cysteine residues. Incubation of the enzyme with radioactive pyruvate, followed by reduction with sodium borohydride, led to inactivation of the enzyme and binding of the pyruvate to the protein by reduction of a Schiff's base initially formed with the $\epsilon$-amino group of a lysine residue; only one-twentieth as many pyruvyl residues were bound by this method, showing that bromopyruvate is not specific for the active site. After protection of the enzyme active site with pyruvate, treatment with unlabelled bromopyruvate and dialysis, the enzyme retained $72 \%$ activity. When this treated enzyme was separately incubated with radioactive bromopyruvate, or radioactive pyruvate followed by sodium borohydride, the ratio of radioactive pyruvyl residues bound by the two methods was 2.3:1. After reduction and hydrolysis of the bromopyruvate-treated enzyme, the only detectable radioactive amino acid derivative was chromatographically and electrophoretically identical with $S$-(3-lactic acid)-cysteine. The enzyme was fully active in the presence of EDTA and was not stimulated by bivalent metal ions. It was strongly inhibited by silver and mercuric ions. The apparent molecular weight, determined by Sephadex chromatography, was 250000 . A mechanism of action is proposed for the enzyme. Bromopyruvate reacts rapidly at $\mathrm{pH} 6.0$ with thiol-containing amino acids. Cysteine appears to react anomalously.
\end{abstract}

$N$-Acetylneuraminic acid aldolase ( $N$-acetylneuraminate $-N$ - acetylmannosamine lyase, EC 4.1.3.3) is widely distributed in animal tissues (Brunetti, Jourdian \& Roseman, 1962) and in bacteria (Comb \& Roseman, 1960). It is a degradative enzyme and has been partially purified from Clostridium perfringens (Brunetti, Swanson \& Roseman, 1963; Comb \& Roseman, 1962), Escherichia coli K-235 (Comb \& Roseman, 1960), pig kidney (Brunetti et al. 1962) and bovine kidney (Sirbasku \& Binkley, 1970).

Despite the considerable interest in the enzyme, hitherto there has been very little information on its mechanism of action. In this paper, we investigate some properties of the enzyme and the nature of the active site, and suggest a mechanism of action for the enzyme. A preliminary report of some of this work has been given (Barnett, 1967).

\section{EXPERIMENTAL}

Bromopyruvic acid was purchased from $\mathrm{BDH}$ Chemicals Ltd. (Poole, Dorset, U.K.), $N$-acetylneuraminic acid and $N$-acetylmannosamine from Koch-Light Laboratories Ltd. (Colnbrook Bucks., U.K.) and Sephadex G-200 and G-25 from Pharmacia (G.B.) Itd., London W.13, U.K. Radioactive [U. $\left.{ }^{14} \mathrm{C}\right]$ pyruvio acid was obtained from The Radioohemical Centre (Amersham, Bucks., U.K.).

Bromo $\left[\mathrm{U} \cdot{ }^{14} \mathrm{C}\right]$ pyruvate. The method for the preparation of bromo[U. $\left.{ }^{14} \mathrm{C}\right]$ pyruvate was similar to that of Meloche (1967). Freshly prepared pyruvic acid (5 mg) (Howard \& Fraser, 1961) was dissolved in acetio acid. This solution was used to dissolve sodium [U-14 ${ }^{14}$ ]pyruvate $(100 \mu \mathrm{Ci}$, $31.5 \mathrm{mCi} / \mathrm{mmol})$. Bromine $(0.1 \mathrm{ml})$ was diluted with acetic acid $(10 \mathrm{ml})$ and $0.75 \mathrm{ml}$ of this solution added to the pyruvate solution. One drop of conc. $\mathrm{H}_{2} \mathrm{SO}_{4}$ was added as a catalyst and the solution heated at $65^{\circ} \mathrm{C}$ under reflux with a $\mathrm{CaCl}_{2}$ drying-tube for $1 \mathrm{~h}$. The solution was evaporated to dryness in vacuo at $40^{\circ} \mathrm{C}$ and the syrup 
left overnight in a vacuum desiccator over $\mathrm{NaOH}$ pellets. The syrup was redissolved in dry acetone, which was reevaporated. This procedure was repeated twice and the resulting syrup dissolved in $100 \mathrm{~mm}$-potassium phosphate buffer, pH $7.2(0.5 \mathrm{ml})$, and used immediately. The purity was tested by t.l.c. on silica gel (Merck) with acetonitrile-acetic acid-water (14:2:5, by vol.) as solvent. Spots were detected with acridine $(0.1 \mathrm{~g}$ in $100 \mathrm{ml}$ of ethanol). Bromopyruvic acid moved 1.28 times as fast as pyruvic acid.

Assay of pyruvic acid and derivatives. Pyruvic acid (2 mM), bromopyruvic acid or fluoropyruvic acid $(0-50 \mu l$, $0-0.1 \mu \mathrm{mol}$ ) was added at room temperature to $0.2 \mathrm{M}$ potassium phosphate buffer, $\mathrm{pH} 7.3(0.3 \mathrm{ml})$, water $(1 \mathrm{ml})$, crystalline lactate dehydrogenase $(20 \mu \mathrm{g})$ and $2 \mathrm{~mm}$ NADH $(0.1 \mathrm{ml})$ in a $1 \mathrm{~cm}$ light-path cell. $E_{340}$ was measured in a Unicam SP. 800 spectrophotometer with a scale expansion by a Smiths Servoscribe recorder. The recorder was adjusted to give full-scale deflexion (100) by 0.2 $\mu \mathrm{mol}$ of NADH. The system reached equilibrium in about $1 \mathrm{~min}$. Under different conditions bromopyruvate will inactivate lactate dehydrogenase (Berghaüser, Falderbaum \& Woenckhaus, 1971).

N-Acetylneuraminic acid aldolase. The enzyme was partially purified by the method of Comb \& Roseman (1962) with some modifications. Cl. perfringens (National Catalogue of Industrial Bacteria, 8875) was grown in batches (4l) and harvested. The protamine sulphate precipitation step of Comb \& Roseman (1962) was omitted. Generally the precipitate formed after dialysis of the $\left(\mathrm{NH}_{4}\right)_{2} \mathrm{SO}_{4}$ precipitate $(60-80 \%)$ was used in inhibition experiments. This material had a specific activity of $24.6 \mathrm{units} / \mathrm{mg}$ of protein. Occasionally the enzyme was further purified by the Sephadex G-200 column used for determination of approximate molecular weight. In this case, the specific activity was 52.1 units/mg but the enzyme was unstable and lost activity on freeze-drying, and could not successfully be used for inhibition experiments.

Enzyme assay. The enzyme was assayed by the method of Brunetti et al. (1962). The $N$-acetylmannosamine produced was measured with $N$-acetylneuraminic acid as substrate. The enzyme was incubated with $10 \mathrm{~mm}-N$ acetylneuraminic acid in $100 \mathrm{~mm}$-potassium phosphate buffer, $\mathrm{pH} 7.2(0.5 \mathrm{ml})$, at $37^{\circ} \mathrm{C}$ for $15 \mathrm{~min}$. The solution was heated at $100^{\circ} \mathrm{C}$ for $2 \mathrm{~min} ; 0.5 \mathrm{ml}$ of water was added and then it was centrifuged. The supernatant $(0.5 \mathrm{ml})$ was incubated with $0.4 \mathrm{M}$-potassium tetraborate, $\mathrm{pH} 9.1$ $(0.5 \mathrm{ml})$, at $100^{\circ} \mathrm{C}$ for $10 \mathrm{~min}$. A solution of $p$-dimethylaminobenzaldehyde $(10 \mathrm{~g})$ in $\mathrm{HCl}(12.5 \mathrm{ml})$ and acetic acid $(87.5 \mathrm{ml})$ was diluted with 9 parts of acetic acid and $3 \mathrm{ml}$ of the diluted solution was added. The mixture was incubated at $37^{\circ} \mathrm{C}$ for $10 \mathrm{~min}$ and the $E_{585}$ read. The activity was expressed in units, where 1 unit represents $1 \mu \mathrm{mol}$ of $N$ acetylmannosamine produced/min under these conditions. This unit is 15 times that used by Brunetti et al. (1963).

Protein determination. Protein was determined either by the method of Lowry, Rosebrough, Farr \& Randall (1951) or by its u.v. absorption at $230 \mathrm{~nm}$. The latter method was generally used for detection of column eluates rather than for quantitative determinations. In each case bovine serum albumin was used as standard.

Apparent-molecular-weight determination. The volume of eluent required to elute the enzyme from a Sephadex G-200 column was determined in comparison with standards of known molecular weight (Andrews, 1965). $N$-Acetylneuraminic acid aldolase $(1 \mathrm{mg}$ ) was dissolved in $0.15 \mathrm{M}$ $\mathrm{KCl}(2 \mathrm{ml})$ with the markers Blue Dextran (1 mg), cytochrome $c(2.5 \mathrm{mg})$, lactate dehydrogenase $(0.1 \mathrm{mg})$, malate dehydrogenase $(0.1 \mathrm{mg})$, catalase $(0.2 \mathrm{mg})$ and urease (0.1 mg) (Fig. 1).

Inactivation of $\mathrm{N}$-acetylneuraminic acid aldolase by bromopyruvate. The enzyme $(0.25 \mathrm{mg}$ of protein) was dissolved in $0.05 \mathrm{M}$-potassium phosphate buffer, pH 7.2 $(5 \mathrm{ml})$. This solution $(50 \mu \mathrm{l})$ was incubated at $37^{\circ} \mathrm{C}$ with bromopyruvate in the same buffer $(50 \mu \mathrm{l}$, final concn. $0.1-5.0 \mathrm{~mm})$. Portions $(10 \mu \mathrm{l})$ were removed at $0.5 \mathrm{~min}$ and at the required times and quickly added to the standard assay system, which contained 1 mm-cysteine to inactivate the bromopyruvate. The enzyme activity was measured and compared with controls treated in the same way but lacking bromopyruvate.

Preparation of bromopyruvate-inactivated enzyme. The bromo[U-14 C]pyruvate solution $(0.4 \mathrm{ml}, 4.4 \mathrm{mg}, 2.86 \mathrm{mCi} /$ mmol) in buffer at pH7.2 was added to the enzyme (13.2 $\mathrm{mg}$ of protein fraction 5 ) in $50 \mathrm{~mm}$-potassium phosphate buffer, pH 7.2 $(0.6 \mathrm{ml})$, and incubated at $37^{\circ} \mathrm{C}$ for 1h. A $10 \mu l$ portion was removed for enzyme assay. There was no activity. The inactivated enzyme was dialysed overnight against water and freeze-dried. It was redissolved in $0.15 \mathrm{M}-\mathrm{KCl}(1.0 \mathrm{ml})$ and added to a Sephadex G-200 column (as for determination of mol.wt.) and eluted with $0.15 \mathrm{M}-\mathrm{KCl}$. The fractions $(3 \mathrm{ml})$ were assayed for protein and radioactivity (Fig. 2). A $0.1 \mathrm{ml}$ sample was added to $5 \mathrm{ml}$ of NE 250 scintillation fluid (Nuclear Enterprises Ltd., Edinburgh, U.K.) and the radioactivity counted by using a Beckman scintillation counter. The fractions containing radioactivity were pooled, dialysed and freeze-dried. The specific radioactivity was $8.35 \times$

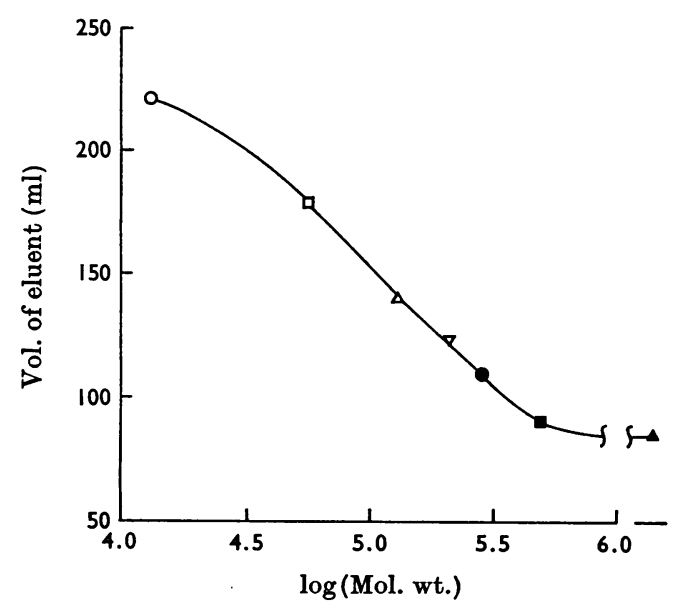

Fig. 1. Determination of molecular weight by the method of Andrews (1965). $N$-Acetylneuraminic acid aldolase (•) was mixed with cytochrome $c(0)$, malate dehydrogenase $(\square)$, lactate dehydrogenase $(\Delta)$, catalase $(\nabla)$, urease $(\square)$ and Blue Dextran $(\Delta)$. The mixture was applied to a Sephadex G-200 column and the elution volume plotted against log (mol.wt.). 


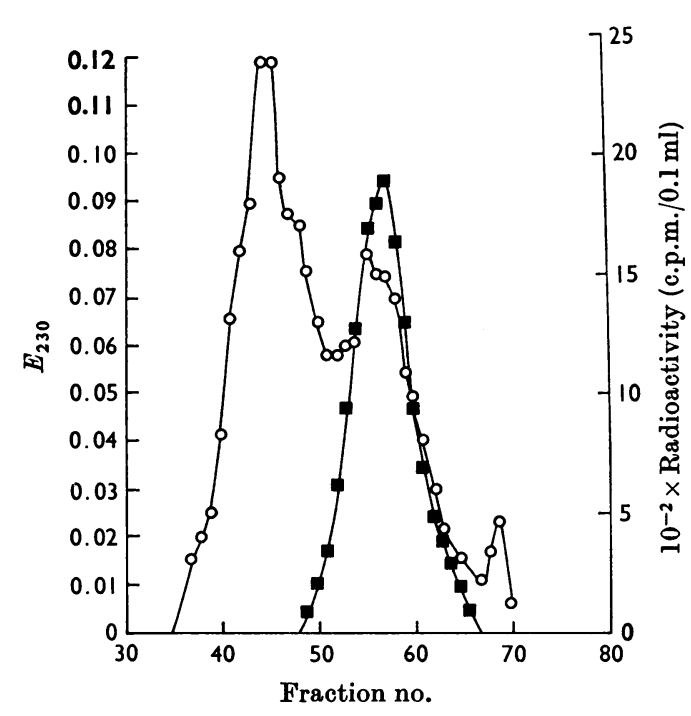

Fig. 2. Chromatography of radioactive, bromopyruvateinactivated, $N$-acetylneuraminic acid aldolase on Sephadex G-200. Fractions $(3 \mathrm{ml})$ were collected and assayed for protein by their extinction at $230 \mathrm{~nm}(O)$ and for radioactivity $(\square)$.

$10^{5} \mathrm{~d}$.p.m./mg of protein, which corresponds to the addition of $34 \mathrm{~mol}$ of bromopyruvate/mol of enzyme, assuming a mol.wt. of 250000 and that the enzyme was pure.

Hydrolysis of the bromo[U-1 $\left.{ }^{14} \mathrm{C}\right]$ pyruvate-inactivated enzyme and identification of the modified amino acid. The radioactive inactivated enzyme was redissolved in water $(1.0 \mathrm{ml})$ and $\mathrm{NaBH}_{4}(8 \mathrm{mg})$ added. The solution was left for $15 \mathrm{~min}$ at room temperature and then $6 \mathrm{M}-\mathrm{HCl}(4.0 \mathrm{ml})$ added. After generated hydrogen had been allowed to escape the vessel was sealed and heated at about $100^{\circ} \mathrm{C}$ for $24 \mathrm{~h}$. The hydrolysate was freeze-dried, redissolved in a little water and again freeze-dried and finally dissolved in $0.5 \mathrm{ml}$ of water. Portions of this hydrolysate were subjected to chromatography and electrophoresis and compared with authentic $S$-(3-lactic acid)-cysteine. The radioactive substance chromatographed and behaved on electrophoresis identically with $S$-(3-lactic acid)-cysteine (Table 2).

Chromatography and electrophoresis. Descending chrom. atography was on Whatman no. 1 paper with solvent 1 , butan-1-ol-acetic acid-water (12:3:5, by vol.), or solvent 2, phenol-water-aq. $\mathrm{NH}_{3}$ (sp. gr. 0.88$)(80: 20: 1$, by vol.). Electrophoresis was performed on the same paper with a Shandon vertical electrophoresis tank and a Vokam power pack at constant voltage $(300 \mathrm{~V})$. The buffers were: $25 \%$ formic acid-acetic acid-water (13:29:258, by vol.), pH 1.9; pyridine-acetic acid-water (50:2:948, by vol.), pH 6.0; sodium diethyl barbiturate-diethylbarbituric acid-water $(10.3: 1.84: 1000, \mathrm{w} / \mathrm{w} / \mathrm{v}) \mathrm{pH}$ 8.6. Radioactive areas were detected with a Baird and Tatlock gas-flow chromatogram scanner.
Inactivation of $\mathrm{N}$-acetylneuraminic acid aldolase with sodium borohydride in the presence of $\left[\mathrm{U}-{ }^{14} \mathrm{C}\right]$ pyruvate. In a preliminary experiment the enzyme $(0.25 \mathrm{mg}$ of protein) was dissolved in $0.05 \mathrm{~m}$-potassium phosphate buffer, $\mathrm{pH} 7.2(5 \mathrm{ml})$. A portion $(20 \mu \mathrm{l})$ was added to a solution $(0.23 \mathrm{ml})$ containing a final concentration of $30 \mathrm{~mm}$ sodium pyruvate in $30 \mathrm{~mm}$-sodium phosphate buffer, $\mathrm{pH}$ 7.2. The solution was left for $5 \mathrm{~min}$ at room temperature and $50 \mu \mathrm{l}$ of $32 \mathrm{~mm}-\mathrm{NaBH}_{4}$ was added; the solution was then incubated at $37^{\circ} \mathrm{C}$ for $30 \mathrm{~min}$. Portions $(50 \mu \mathrm{l})$ were assayed for enzyme activity. The enzyme was completely inactive in contrast with controls lacking pyruvate or $\mathrm{NaBH}_{4}$, which were fully active.

The enzyme (27 $\mathrm{mg}$ of protein, fraction 5) was dissolved in $45 \mathrm{~mm}$-potassium phosphate buffer, $\mathrm{pH} 7.2$ (1 ml), and $50 \mu \mathrm{l}$ of $\left[\mathrm{U}-{ }^{14} \mathrm{C}\right]$ pyruvate $(16.6 \mu \mathrm{Ci}, 0.53 \mu \mathrm{mol} ; 31.5 \mathrm{mCi} /$ mmol) was added. The mixture was allowed to stand at room temperature for $10 \mathrm{~min}$ and then $0.1 \mathrm{ml}$ of $1 \mathrm{M}$ $\mathrm{NaBH}_{4}$ added. After $10 \mathrm{~min} 50 \mu \mathrm{l}$ of $2 \mathrm{M}$-acetic acid was added. The addition of $\mathrm{NaBH}_{4}$ and acetic acid was repeated three or four times. A $20 \mu$ l sample was assayed for enzyme activity and the solution dialysed against water ( $800 \mathrm{vol}$.) for $12 \mathrm{~h}$ with three or four changes of fresh water. The enzyme was $37 \%$ inactivated. A second similar sample was treated as the first, but without the treatment with $\mathrm{NaBH}_{4}$. It was not inactivated and was used as blank for the calculation of radioactivity incorporated into protein.

The radioactive enzyme derivative was freeze-dried, dissolved in $2.0 \mathrm{ml}$ of $0.15 \mathrm{M}-\mathrm{KCl}$ and passed through a column of Sephadex G-200. The fractions containing radioactivity (Fig. 3) were collected.

The specific radioactivity was $1.42 \times 10^{5}$ d.p.m. $/ \mathrm{mg}$ of protein, which corresponds to the addition of about $1.5 \mathrm{~mol}$ of pyruvate/mol of enzyme, assuming a mol.wt. of 250000 , that the enzyme was pure and that the inactivation (37\%) was due to attachment of pyruvate so that only inactive enzyme contained radioactivity.

Hydrolysis of the sodium borohydride-stabilized enzymesubstrate complex and identification of the radioactive amino acid derivative. The freeze-dried enzyme was suspended in $6 \mathrm{M}-\mathrm{HCl}$ and heated at $110^{\circ} \mathrm{C}$ in a sealed tube for $24 \mathrm{~h}$. The product was evaporated to dryness in vacuo, water was added and re-evaporated, and the residue redissolved in water $(1 \mathrm{ml})$. This solution was used for comparison of paper-chromatographic and electrophoretic properties with $N^{6}$-(1-carboxyethyl)-lysine (Ingram \& Wood, 1965) (Table 2).

Treatment of a 'pyruvate-protected' enzyme with unlabelled bromopyruvate and the preparation of radioactive pyruvate-sodium borohydride and bromopyruvate derivatives. Purified $N$-acetylneuraminic acid aldolase (fraction $5 ; 22 \mathrm{mg}$ of protein) in $50 \mathrm{~mm}$-potassium phosphate buffer, pH 7.2 (1.0 ml), containing $40 \mathrm{~mm}$-pyruvate was treated with $1 \mathrm{~mm}$-bromopyruvate at $37^{\circ} \mathrm{C}$. After $30 \mathrm{~min} 0.8 \mathrm{~g}$ of $\left(\mathrm{NH}_{4}\right)_{2} \mathrm{SO}_{4}$ was added to the ice-cooled solution and after a further $30 \mathrm{~min}$ the precipitate was centrifuged and redissolved in $2.0 \mathrm{ml}$ of water and dialysed against water at $2^{\circ} \mathrm{C}$ overnight. The enzyme retained $72 \%$ of its original activity.

The pretreated enzyme $(1.0 \mathrm{ml}, 9.5 \mathrm{mg}$ of protein, 151 units) was inactivated by $10 \mathrm{~mm}$-bromo[U-14 $\mathrm{C}]$ pyruvate $\left(10.3 \mu \mathrm{mol}, 2.65 \times 10^{6} \mathrm{~d} . \mathrm{p} . \mathrm{m} . / \mu \mathrm{mol}\right)$ for $24 \mathrm{~h}$ at $37^{\circ} \mathrm{C}$. The enzyme then had no catalytic activity. The protein was 

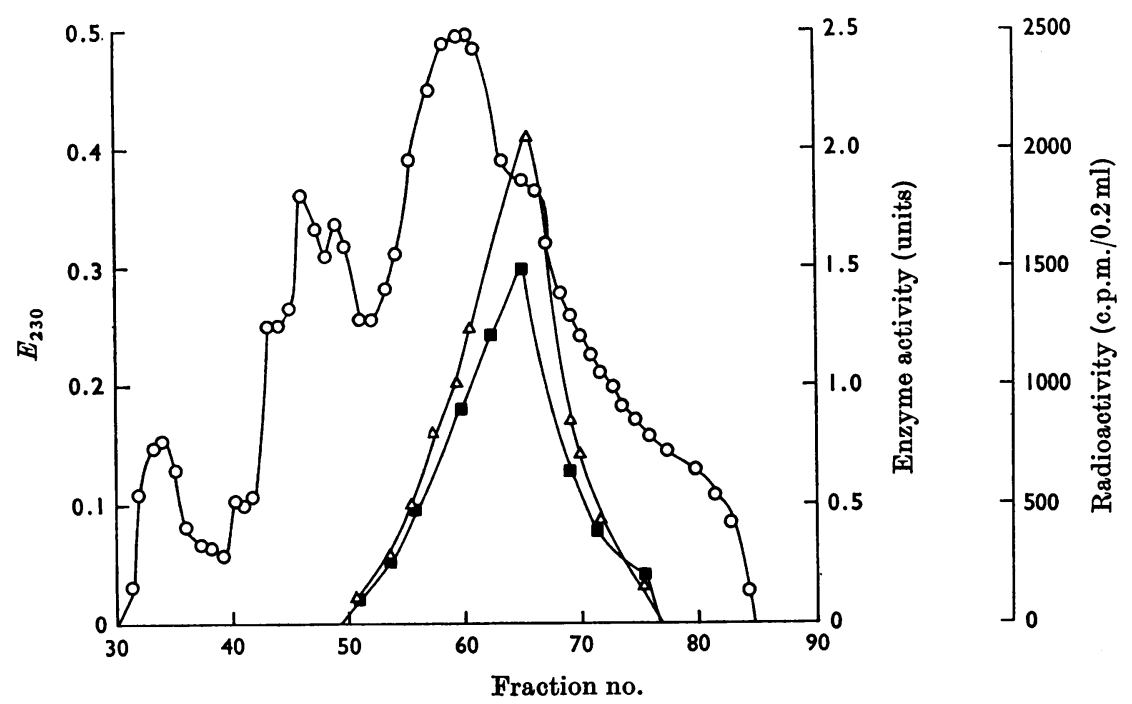

Fig. 3. Chromatography of radioactive, pyruvate- $\mathrm{NaBH}_{4}$-inactivated $\mathrm{N}$-acetylneuraminic acid aldolase on Sephadex G-200. Fractions $(3 \mathrm{ml})$ were collected and assayed for enzyme activity $(\Delta)$, protein by the extinction at $230 \mathrm{~nm}(\mathrm{O})$, and radioactivity $(\boldsymbol{\square})$.

precipitated by $\left(\mathrm{NH}_{4}\right)_{2} \mathrm{SO}_{4}(1.6 \mathrm{~g})$ and centrifuged. It was dissolved in $3.0 \mathrm{ml}$ of water and dialysed against water at $2^{\circ} \mathrm{C}$ (four changes) over $24 \mathrm{~h}$. The solution was freezedried and redissolved in $2 \mathrm{ml}$ of $0.15 \mathrm{~m}-\mathrm{KCl}$. This solution was chromatographed on a column $(35 \mathrm{~cm} \times 2.5 \mathrm{~cm})$ of Sephadex G-25; $0.15 \mathrm{M}-\mathrm{KCl}$ was used for elution and $3 \mathrm{ml}$ fractions were collected. Two radioactive peaks were observed, one of which coincided exactly with the protein peak (Fig. 4). Fractions containing protein were pooled and dialysed against water and then contained $0.5 \mathrm{mg}$ of protein and $8.5 \times 10^{4} \mathrm{~d} . \mathrm{p} . \mathrm{m} . / \mathrm{mg}$. This corresponds to $8.7 \mathrm{~mol}$ of pyruvate bound $/ \mathrm{mol}$ of enzyme, calculated as if it were pure and assuming a mol.wt. of 250000 .

Another sample of the pretreated enzyme was also treated with $\left[\mathrm{U}-{ }^{14} \mathrm{C}\right]$ pyruvate- $\mathrm{NaBH}_{4}$. The pretreated enzyme (7.0 mg, 72.7 units) in $50 \mathrm{~mm}$-potassium phosphate buffer, $\mathrm{pH} 7.2(0.5 \mathrm{ml})$, was incubated at $37^{\circ} \mathrm{C}$ with $5.0 \mathrm{~mm}$-pyruvate $\left(2.5 \mu \mathrm{mol}, 5.5 \times 10^{7}\right.$ d.p.m. $)$ for $10 \mathrm{~min}$ and $0.1 \mathrm{ml}$ of $1 \mathrm{M}-\mathrm{NaBH}_{4}$ added. After $10-15 \mathrm{~min}, 2 \mathrm{M}$-acetic acid $(50 \mu \mathrm{l})$ was added. The addition of $\mathrm{NaBH}_{4}$ and acetic acid was repeated four or five times. After dialysis the enzyme had $19 \%$ of its original activity. The freezedried solution was applied to the Sephadex G-25 column and eluted with $0.15 \mathrm{M}-\mathrm{KCl}$. The protein gave one peak, which corresponded to the radioactive peak. The protein fractions were pooled, dialysed and freeze-dried $(5.08 \times$ $10^{5} \mathrm{~d}$.p.m./1.46 mg of inactivated protein). The apparent number of pyruvate residues bound $/ \mathrm{mol}$ of inactivated enzyme was 3.9, assuming mol.wt. 250000 and calculated as if the enzyme were pure.

Preparation of S-(3-lactic acid)-cysteine. N-Acetyloysteine $(100 \mu \mathrm{mol})$ was dissolved in water $(1.5 \mathrm{ml})$ and $0.1 \mathrm{~m}-\mathrm{NaOH}(1 \mathrm{ml})$ added. The $\mathrm{pH}$ was adjusted to $\mathrm{pH} 6.0$ in a pH-stat (Radiometer, Copenhagen). Bromopyruvate $(100 \mu \mathrm{mol})$ was neutralized in the same way to $\mathrm{pH} 6.0$.

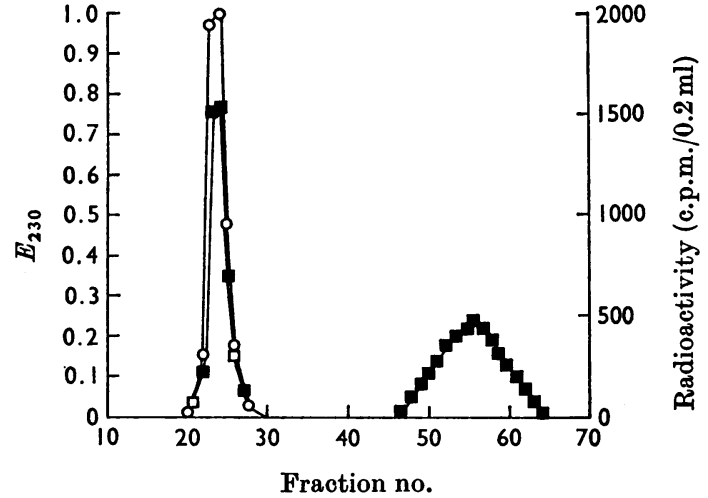

Fig. 4. Chromatography of bromo[U-14 C]pyruvateinactivated, 'pyruvate-protected', $N$-acetylneuraminic acid aldolase on Sephadex G-25. Fractions $(3 \mathrm{ml})$ were collected and assayed for protein by their extinction at $230 \mathrm{~nm}(\mathrm{O})$, and for radioactivity (a).

The two solutions were mixed in the pH-stat and the acid released at $\mathrm{pH} 6.0$ and $25^{\circ} \mathrm{C}$ was automatically titrated with $0.1 \mathrm{~m}-\mathrm{NaOH}$. When the reaction had finished, $\mathrm{NaBH}_{4}(400 \mu \mathrm{mol})$ was added. The solution was deionized with Amberlite IR 120 (H form) and evaporated to dryness in vacuo. Methanol was added and removed several times to remove boric acid, and then $6 \mathrm{M}-\mathrm{HCl}$ was added. The solution was heated in a sealed tube at $110^{\circ} \mathrm{C}$ for $24 \mathrm{~h}$ and evaporated to dryness in vacuo. Water was added and removed in vacuo several times to remove traces of 


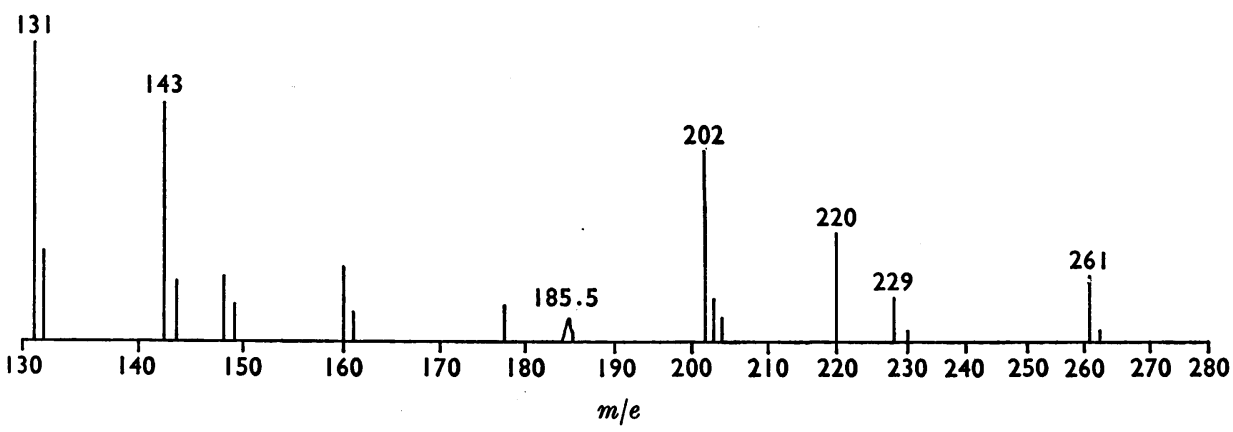

Fig. 5. Mass spectrum of $N$-acetyl-S-(3-lactio aoid)-oysteine dimethyl ester. The highest $m / e$ observed is 261 , which corresponds to $M-18$ by dehydration of the lactic acid residue. The peak at 220(M-59) corresponds to loss of $\mathrm{CO}_{2}-\mathrm{CH}_{3}$ and the peak at 202(M-59-18) to loss of water and $\mathrm{CO}_{2}-\mathrm{CH}_{3}$. The metastable peak at 185.5 is the product of this transition.

HCl. The residue ran as a single spot on chromatography and electrophoresis.

$\mathrm{N}$ - Acetyl-S - (3 - lactic acid) - cysteine dimethyl ester. $N$-Acetyloysteine was treated as described above, but after removal of the boric acid, the $N$-acetyl-S-(3-lactio acid)-cysteine was dissolved in methanol $(2 \mathrm{ml})$ and a strong solution of diazomethane in ether was added to a persistent yellow. Evaporation in vacuo gave the product, characterized by mass spectrometry (Fig. 5).

Rate of reaction of bromopyruvate, chloroacetaldehyde and iodoacetamide with amino acids. The amino acid and alkýlating agent were adjusted to the required $\mathrm{pH}$ (usually 6.0) in the pH-stat. Solutions were kept at the temperature subsequently to be used in the experiment. The amino acid $(0.1 \mathrm{ml}, 1 \mu \mathrm{mol})$ was added to water $(4.8 \mathrm{ml})$ in a jacketted cell. The $\mathrm{pH}$ was readjusted to that required with the $\mathrm{pH}$-stat and preincubated to allow the cell contents to reach the reaction temperature. Then bromopyruvate $(0.1 \mathrm{ml}, 10 \mu \mathrm{mol})$ was added and the $\mathrm{pH}$ maintained by automatic addition of $0.01 \mathrm{M}-\mathrm{NaOH}$ by using a burette of maximum capacity $0.25 \mathrm{ml}$.

Occasionally $0.1 \mathrm{ml}$ was withdrawn just before addition of the bromopyruvate for assay of thiol groups by 5,5 'dithiobis-(2-nitrobenzoic acid) (Ellman, 1959).

If the amino acid showed no reaction under these conditions, the same procedure was used, but $100 \mu \mathrm{mol}$ of amino acid was added and the reaction followed by using $0.1 \mathrm{M}-\mathrm{NaOH}$ at $25^{\circ} \mathrm{C}$. Under these conditions a slow spontaneous rate of hydrolysis of bromopyruvate was observed.

Quantitative ninhydrin assay. The product of reaction with cysteine was assayed by the method of Moore \& Stein (1948) by using a cysteine standard curve.

\section{RESULTS}

Partial purification of $\mathrm{N}$-acetylneuraminic acid aldolase and determination of apparent molecular weight. Table 1 shows the stages of purification of the enzyme. The final material obtained after Sephadex chromatography still gave two bands of relative intensity $1: 5$ on cellulose acetate electro- phoresis at pH 8.6. The apparent molecular weight was about 250000 (Fig. 1).

Effect of EDTA and metal ions. EDTA (10 mM) added to the standard enzyme assay had no effect on enzyme activity. The following cations (1 mM), tested as the chlorides, were added and had no effect: $\mathrm{Ni}^{2+}, \mathrm{Fe}^{2+}, \mathrm{Ca}^{2+}, \mathrm{Mg}^{2+}$ and $\mathrm{Mn}^{2+}$. Zinc chloride inhibited by $20 \%$, and silver nitrate inhibited by $92 \%$, mercuric chloride by $99 \%$ and copper sulphate by $26.0 \%$.

$K_{m}$ for $\mathrm{N}$-acetylneuraminic acid and $K_{t}$ for pyruvic acid. The $K_{m}$ was determined in the concentration range $1.0-10.0 \mathrm{~mm}$ in the presence and absence of $10 \mathrm{~mm}$-pyruvate. The $K_{m}, 3.3 \mathrm{~mm}$, compares with that of $3.9 \mathrm{~mm}$ found by Comb \& Roseman (1960). The inhibition by pyruvic acid was competitive, $K_{t}$ being $3.0 \mathrm{~mm}$.

Inactivation by bromopyruvate. The enzyme was incubated with 1 mM-bromopyruvate at $\mathrm{pH} 7.2$ and $37^{\circ} \mathrm{C}$. The enzyme activity was determined at various time-intervals and compared with a control incubated in the same way but without bromopyruvate. The control did not lose activity. The percentage activity was recorded and log percentage activity plotted against time. This gave a straightline relationship representing the apparent firstorder decay of enzyme activity. From this both the apparent first-order rate constant and the half-life $\left(t_{t}\right)$ were determined. Under these conditions $t_{t}$ was $4.2 \mathrm{~min}$. In the presence of $10 \mathrm{~mm}$ $N$-acetylmannosamine this value was unaltered whereas in the presence of $10 \mathrm{~mm}$-pyruvate, the $t_{*}$ increased to $18.7 \mathrm{~min}$, showing protection (Fig. 6).

Apparent reversible binding constant $\left(K_{\ell}\right)$ for bromopyruvate. The enzyme was incubated with various concentrations of bromopyruvate (0.1$5.0 \mathrm{~mm}$ ) and portions were assayed for enzyme activity after various times as described above (Fig. 7). The first-order rates of reaction tended 
Table 1. Purification of $\mathrm{N}$-acetylneuraminic acid aldolase

For details see the Experimental section and Comb \& Roseman (1962).

$\begin{array}{lccc}\text { Fraction } & \begin{array}{c}\text { Total } \\ \text { units }\end{array} & \begin{array}{c}\text { Specific activity } \\ \text { (units/mg of protein) }\end{array} & \text { Purification } \\ \text { 1. Crude extract } & 1610 & 0.48 & 1 \\ \text { 2. Bentonite } & 1399 & 0.93 & 1.9 \\ \text { 3. Polymixin } & 1177 & 0.82 & 1.7 \\ \text { 4. Heat } & 534 & 1.23 & 2.6 \\ \text { 5. }\left(\mathrm{NH}_{4}\right)_{2} \mathrm{SO}_{4} & 437 & 24.6 & 51 \\ \text { 6. Sephadex eluate } & 194 & 52.1 & 108 \\ \text { 7. Freeze-dried } & 75 & 20.6 & 42\end{array}$

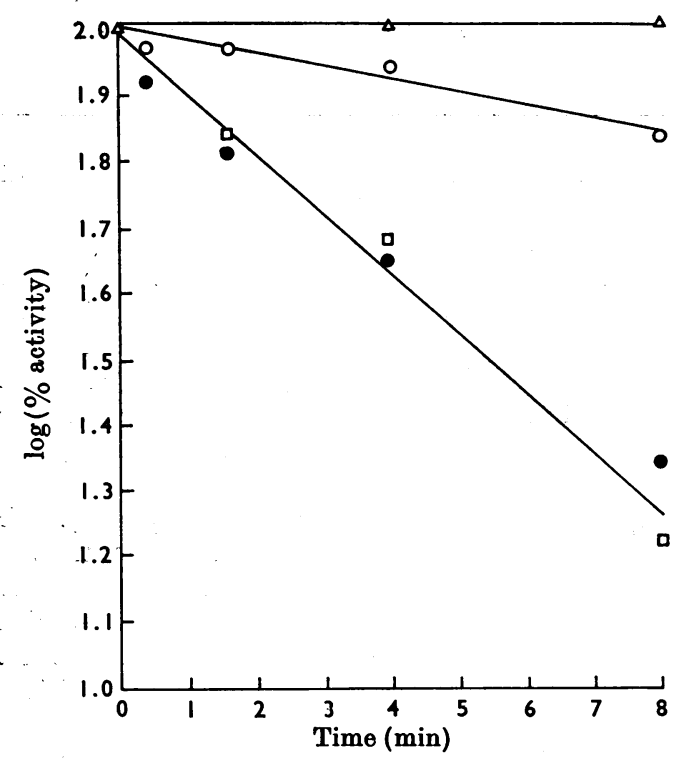

Fig. 6. Effect of $10 \mathrm{~mm}$-pyruvate and $10 \mathrm{~mm}-N$-acetylmannosamine on the rate of inactivation of $N$-acetylneuraminic acid aldolase by $1 \mathrm{~mm}$-bromopyruvate. The enzyme activity of samples removed at the time-intervals shown is recorded as the logarithm of the percentage of initial activity. $\Delta$, No addition; $\bullet$, with bromopyruvate alone; $O$, with bromopyruvate and pyruvate; $\square$, with bromopyruvate and $N$-acetylmannosamine.

to a maximum with increasing concentration as would be expected of the equilibrium $\mathbf{E}+\mathbf{I} \rightleftharpoons \mathbf{E I} \rightarrow \mathrm{EI}^{*}$ in which $\mathbf{E I}$ is an intermediate and complex EI* is the final covalently bonded enzyme-inhibitor complex. The maximum rate (minimum $t_{t}$ ) represents the first-order rate of reaction of the EI complex and is independent of enzyme concentration. A Lineweaver-Burk plot of $t_{\text {t }}$ against the reciprocal of substrate concentration (Fig. 8) gives the maximum first-order rate constant, $k$, at $\mathrm{pH} 7.2$ and $37^{\circ} \mathrm{C}$, as $3.3 \times 10^{-3} \mathrm{~s}^{-1}$ (minimum $t_{\frac{1}{2}} 2.6 \mathrm{~min}$ ) and the apparent $K_{\imath} 0.46 \mathrm{~mm}$.

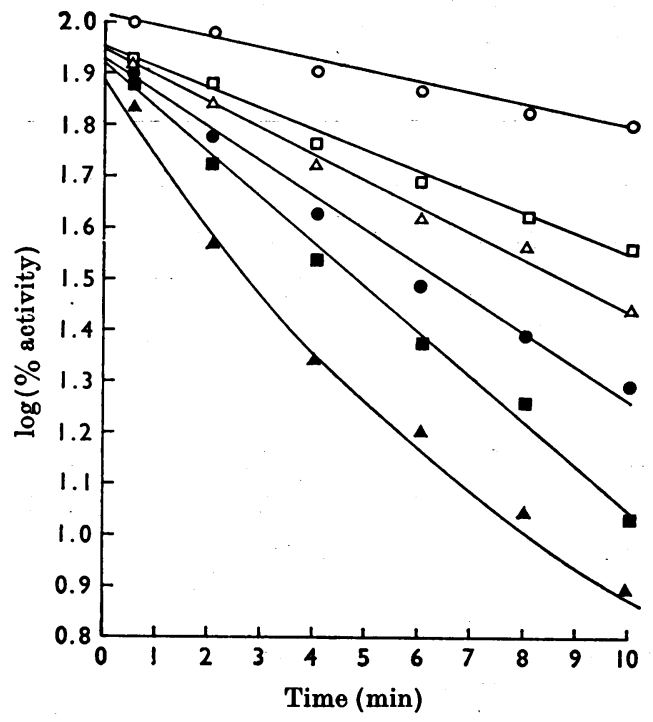

Fig. 7. Rate of inactivation of $N$-acetylneuraminic acid aldolase by different concentrations of bromopyruvic acid: $O, 0.1 \mathrm{~mm} ; \square, 0.25 \mathrm{~mm} ; \Delta, 0.5 \mathrm{~mm} ; \bullet, 1.0 \mathrm{~mm}$; $\square, 2.0 \mathrm{~mm} ; \Delta, 5.0 \mathrm{~mm}$. The enzyme activity of samples removed at the time-intervals shown is recorded as $\log$ (\% initial activity).

Identity of the amino acid modified by sodium borohydride and pyruvate. The enzyme was treated with $\left[\mathrm{U}^{14} \mathrm{C}\right]$ pyruvate and sodium borohydride as described in the Experimental section. The fractions containing the enzymic activity and radioactivity eluted from Sephadex G-200 of the $37 \%$-inhibited enzyme were pooled and hydrolysed to give a single radioactive compound, which had identical chromatographic mobility with $N^{6}$. (1-carboxyethyl)-lysine (Table 2). On paper electrophoresis, its mobility was close to that of glutamic acid, as might be expected from its structure.

Identity of the amino acid modified by bromopyruvate. The enzyme treated with bromo[U-14 C]- 
pyruvate was chromatographed on Sephadex G-200 and the radioactive fractions were pooled, reduced with sodium borohydride to stabilize the derivative, and hydrolysed. It gave one main peak of radioactivity on chromatography and electrophoresis, which was identical with $S$-(3-lactic acid)-cysteine prepared from $N$-acetylcysteine (Table 2).

Reaction of 'pyruvate-protected' enzyme with unlabelled bromopyruvate and identification of residues subsequently alkylated by bromo[U-14C]pyruvate. The enzyme was treated with unlabelled $1 \mathrm{~mm}$ bromopyruvate in the presence of $40 \mathrm{~mm}$-pyruvate. After dialysis the resulting enzyme had $72 \%$ of the original enzyme activity. The treated enzyme was inactivated with radioactive bromopyruvate. The

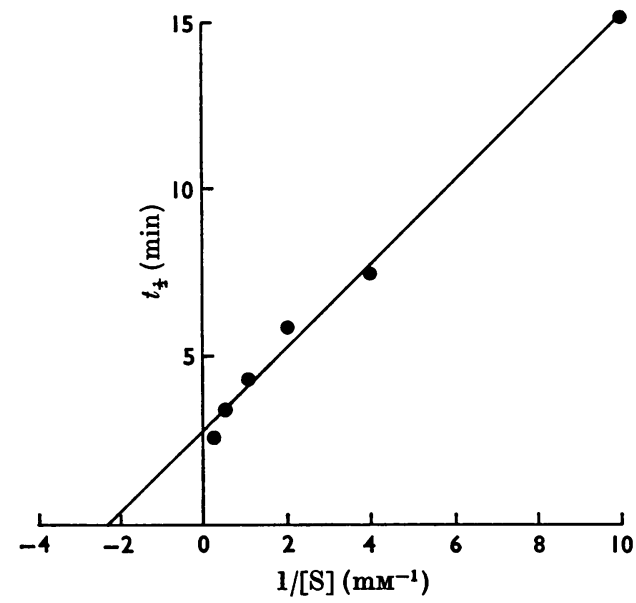

Fig. 8. Plot of $t_{t}$ (half-life) for the apparent first-order inactivation of $N$-acetylneuraminic acid aldolase against the reciprocal of the bromopyruvate concentration. The values of $t_{t}$ are obtained from Fig. 7 . only radioactive amino acid derivative detectable after borohydride reduction and hydrolysis was $S$-(3-lactic acid)-cysteine.

Molar ratios of pyruvate residues incorporated into $\mathrm{N}$-acetylneuraminate aldolase by bromopyruvate or pyruvate-sodium borohydride. Assuming mol.wt. of 250000 , and that the enzyme was pure, the number of residues of pyruvate bound $/ \mathrm{mol}$ of enzyme in the Sephadex-purified fractions was: unprotected enzyme, bromopyruvate 34 , pyruvatesodium borohydride 1.5; 'pyruvate-protected' enzyme, bromopyruvate 8.7, pyruvate-sodium borohydride 3.9. The low value for the pyruvatesodium borohydride treatment of the unprotected enzyme may be due to the error in the amount of inhibition ascribed to the specific inhibition due to formation of Schiff's base. A small amount of indiscriminate inhibition would alter the apparent value by a significant amount. Since the enzyme was impure, the values given should be regarded as very approximate.

Reaction of bromopyruvate with thiol compounds. Bromopyruvate reacted extremely rapidly with thiol compounds (Table 3). The products had properties consistent with the formation of the $S$-(3-pyruvic acid)- derivative.

\section{DISCUSSION}

Aldolases fall into two classes: those which are catalysed by bivalent metal ions (type II) and those in which the reactivity of the substrate is enhanced by formation of a Schiff's base between the ketonic substrate and an amino group of the enzyme (type I). The two types of enzyme can be readily distinguished by their difference in behaviour towards chelating agents and sodium borohydride in the presence of the ketonic substrate, which inhibit the type II and type I

Table 2. Identification of labelled $\mathrm{N}$-acetylneuraminic acid aldolase hydrolysates by chromatography and electrophoresis

For details see the text.

Substance
Lysine
Glutamic acid
Glycine
Hydrolysate after
$[$ U-14C]pyruvate-NaBH
$N^{6}$-(1-Carboxyethyl)-lysine
(literature)
S-(3-Lactic acid)-cysteine
Hydrolysate after
[U-14C]bromopyruvate

Substance

Glycine

ydrolysate after

[U.14]pyruvate-NaBH (literature)

$\left[\mathrm{U}-{ }^{14} \mathrm{C}\right]$ bromopyruvate

\begin{tabular}{|c|c|c|c|c|}
\hline \multicolumn{2}{|c|}{$R_{F}$} & \multicolumn{3}{|c|}{ Electrophoresis (cm) } \\
\hline Solvent 1 & Solvent 2 & $\mathrm{pH} 1.9$ & pH 6.0 & pH 8.6 \\
\hline 0.13 & 0.80 & 14 & 一 & - \\
\hline - & - & 4.5 & - & - \\
\hline - & - & 8.0 & - & - \\
\hline 0.095 & 0.75 & 5.0 & 一 & - \\
\hline 0.087 & 0.73 & - & - & - \\
\hline 0.16 & 0.053 & 1.0 & 4.5 & 6.0 \\
\hline 0.16 & 0.053 & 1.0 & 4.5 & 6.0 \\
\hline
\end{tabular}


Table 3. Rate of reaction of thiol compound with bromopyruvate at $10^{\circ} \mathrm{C}$

The conditions are described in the text.

\begin{tabular}{llcc} 
pH & \multicolumn{1}{|c}{ Thiol compound } & $\begin{array}{c}\text { Acid produced } \\
(\mathrm{mol} / \mathrm{mol})\end{array}$ & $\begin{array}{c}\text { Second-order rate } \\
\text { constant } \\
\left(\mu \mathrm{mol} \cdot \mathrm{s}^{-1} \cdot \mathrm{l}^{-1}\right)\end{array}$ \\
6.0 & $N$-Acetylcysteine & 1.05 & 15 \\
5.5 & $N$-Acetyloysteine & - & 12.5 \\
6.5 & $N$-Acetylcysteine & - & 25 \\
6.0 & Cysteine & 1.9 & 34 \\
6.0 & Homocysteine & 1.0 & 26 \\
6.0 & Glutathione (reduced) & 1.1 & 23
\end{tabular}<smiles>CC(NCC(N)C(=O)O)C(=O)O</smiles>

(I)

enzymes respectively (Rutter, 1964; Morse \& Horecker, 1968).

$N$-Acetylneuraminic acid aldolase was tested for inhibition in these two ways. Whereas EDTA had no effect on the enzyme activity, sodium borohydride in the presence of the substrate, pyruvate, rapidly inactivated the enzyme. When [U. $\left.{ }^{14} \mathrm{C}\right]$ pyruvate was used a radioactive substance was isolated after hydrolysis, chromatographically identical with $N^{6}$-(1-carboxyethyl)-lysine (I) (Table 2). This substance was obtained by Ingram \& Wood (1965) in a similar sodium borohydride reduction of pyruvate and 3-deoxy-2-oxogluconic acid 6-phosphate lyase (3-deoxy-2-oxo-D-gluconate 6-phosphate-D-glyceraldehyde 3-phosphate lyase, EC 4.1.2.c). The hydrolysate was also subjected to electrophoresis at pH 1.9. The mobility of the radioactive derivative resembled that of glutamic acid rather than glycine or lysine, as might be expected from inspection of structure (I). These results indicate that the substrate pyruvate is bound to the enzyme as a Schiff's base with lysine.

The enzyme used in these studies was not pure and therefore calculations of the number of molecules of pyruvate bound to the enzyme should be regarded with extreme caution. However, if it is assumed that this fraction comprised only enzymically active, or radioactive inactivated enzyme, the number of mol of pyruvate bound was about $1.5 \mathrm{~mol} /$ mol of inactivated enzyme, if a mol.wt. of 250000 is assumed. In a subsequent experiment the value was $3.9 \mathrm{~mol} / \mathrm{mol}$.
The mechanism of aldolase catalysis (Scheme 1) requires a group close to the point of condensation able to accept the proton liberated. Such a group should also act as a nucleophile. We therefore tested bromopyruvate as an analogue of pyruvate. The nucleophile on the enzyme might be expected to displace bromide ion to form a stable covalent enzyme derivative. A preliminary report of the inactivation of $N$-acetylneuraminic acid aldolase with bromopyruvate has been published (Barnett, 1967), and the same reagent has been used with two other aldolases, 3-deoxy-2-oxo-D-gluconate 6-phosphate-D-glyceraldehyde 3-phosphate lyase (Meloche, 1967, 1970) and isocitrate lyase (Roche \& McFadden, 1969). In both of these, and with anthranilate synthetase (Zalkin \& Kling, 1968), 3 - deoxy - D - arabino - heptulosonate synthetase (Staub \& Denes, 1967), aspartate aminotransferase (Morino \& Okamato, 1970), and lactate dehydrogenase (Berghaüser et al. 1971) the bromopyruvate can be regarded as a substrate or product analogue. Bromopyruvate has also been shown to react with yeast alcohol dehydrogenase (Rashed \& Rabin, 1968) and glutamate dehydrogenase (Baker \& Rabin, 1969).

Initial experiments were directed towards confirming that bromopyruvate reacted with $N$-acetylneuraminic acid aldolase at, or close to, the pyruvate-binding site. $N$-Acetylmannosamine gave no protection to the enzyme against inactivation by bromopyruvate, but pyruvate $(10 \mathrm{~mm})$ increased the half-life of inactivation from 4.7 to $24 \mathrm{~min}$ when $1 \mathrm{~mm}$-bromopyruvate at $\mathrm{pH} 7.2$ and $37^{\circ} \mathrm{C}$ was used (Fig. 6). Thus one group on the enzyme with which bromopyruvate reacts must be close to the pyruvate-binding site, or alternatively bromopyruvate cannot inactivate the conformation of the enzyme produced by bound pyruvate.

It has been shown that substrate-directed alkylating inhibitors show saturating rates of in. activation, similar to that observed for the catalytic activity of the enzyme. The saturation corresponds to the maximum rate of reaction of the physically bound enzyme-inhibitor complex to give a covalent 


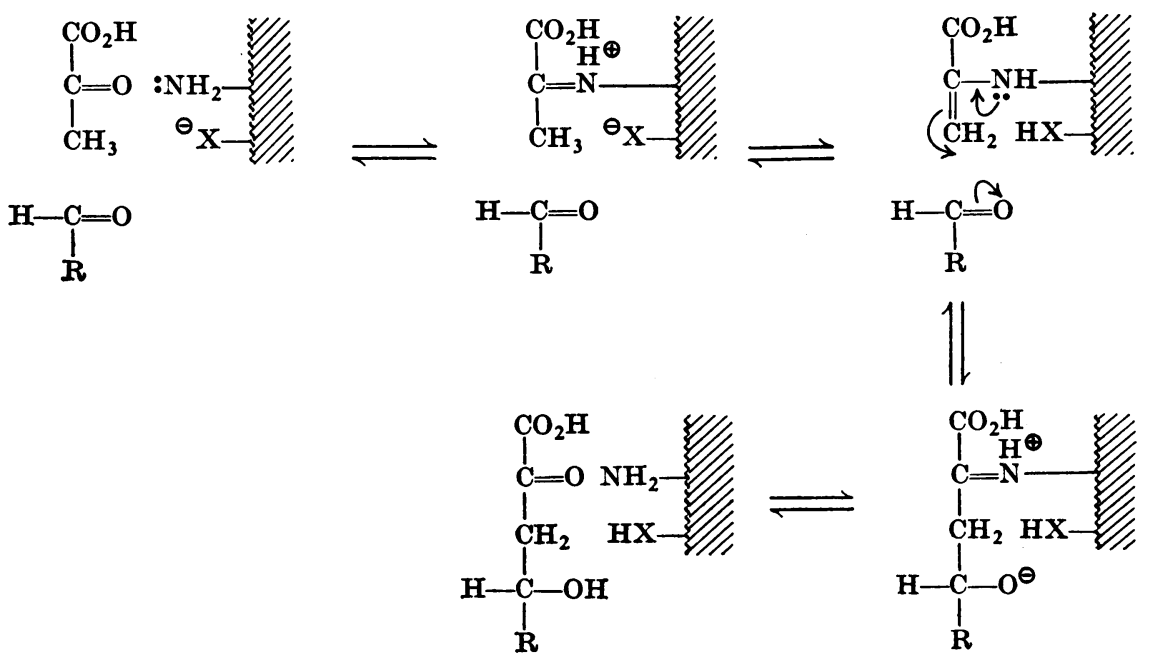

Scheme 1. Possible mechanism for $N$-acetylneuraminic acid aldolase. RCHO, $N$-acetylmannosamine.

bond. The kinetics of this reaction have been discussed by Meloche (1967).

By plotting the reciprocal of the first-order reaction rate (or alternatively by plotting the half-life) determined from plots of the rate of inactivation at different bromopyruvate concentrations (Fig. 7), against the reciprocal of the bromopyruvate concentration (Fig. 8), it is possible to obtain an apparent $K_{m}$ for bromopyruvate. The value, $0.46 \mathrm{~mm}$, compares with the value of $K_{l}(3.0 \mathrm{~mm})$ for pyruvate by using $N$-acetylneuraminic acid as substrate. The maximum inactivation rate, $k 3.3 \times 10^{-3}$, corresponds to the first-order rate of reaction of the enzyme-inhibitor complex and is a true rate constant.

To find the nature of the residues alkylated, radioactive bromopyruvate was prepared and used to inactivate the enzyme. After passage through Sephadex G-200 the radioactive fractions were pooled and reduced with sodium borohydride. We had shown in model experiments that the $S$ pyruvyl residue is destroyed by the acid-hydrolysis conditions used to degrade the protein, whereas the $S$-lactyl residue was stable. Hydrolysis of the reduced protein gave only one detectable radioactive compound, which was identical with $S$-(3lactic acid)-cysteine, characterized by mass spectrometry, in three chromatographic solvents and electrophoresis at three $\mathrm{pH}$ values (Table 2 ). The apparent ratio of mol of pyruvate residues bound to the enzyme with bromopyruvate and pyruvatesodium borohydride as inactivating agents was about $20: 1$. The rapid rate of reaction of bromopyruvate with thiol compounds (Table 3) suggests that any free and available thiol group will react with bromopyruvate. In an attempt to block those thiol residues not at the active site, the enzyme was treated with unlabelled bromopyruvate in the presence of the competitive inhibitor, pyruvate. After dialysis, the enzyme retained $72 \%$ of the original activity and this modified enzyme was treated with radioactive bromopyruvate. The ratio of pyruvate residues bound to the enzyme by the two respective methods was now 2.3:1. This value of about 2 cysteine residues modified for each lysine residue should not be regarded as indicating that there are 2 masked cysteines per active-site lysine, since it is probable that some of the cysteine now reacting with radioactive bromopyruvate will correspond to cysteine residues incompletely reacted with unlabelled bromopyruvate during the preincubation in the presence of the competitive inhibitor.

$S$-(3-Lactic acid)-cysteine was the only radioactive hydrolysis product detected although now a second radioactive substance derived from the active site amino acids should have been detectable. It therefore seems probable that a cysteine residue is at the enzyme active site and reacts with bromopyruvate, although the experiments do not preclude a residue such as glutamate in which the hydroxypyruvate ester formed would be unstable. If cysteine is at the enzyme active site, as suggested by these experiments, the enzyme should be inhibited by heavy-metal ions. Mercuric and silver ions were tested, and they were found to be very inhibitory.

Thus $C l$. perfringens $N$-acetylneuraminic acid aldolase seems to be a typical class I aldolase, using a Schiff's base with a lysine residue to activate the substrate. A residue at the active site, 
<smiles>O=C(O)C1=CSCC(C(=O)O)N1</smiles>

(II)<smiles>O=C(O)CC1=C(C(=O)O)NC(C(=O)O)CS1</smiles>

(III) which may be cysteine, reacts with bromopyruvate to form an inactive enzyme complex, and is probably responsible for accepting the proton lost during an aldol condensation (Scheme 1).

Theindiscriminate and rapid attack on thiol groups (Table 3) suggests that bromopyruvate and similar small haloketones are not entirely suitable as specific substrate-directed inactivators. However, its high reactivity at low pH makes bromopyruvate a suitable non-specific alkylating agent. It reacts with thiols significantly faster than chloroacetaldehyde or iodoacetamide. At pH 6.0 and $25^{\circ} \mathrm{C}$ it does not react at a significant rate with glycine, lysine, methionine, histidine or serine, although in enzymes it has been reported to react with glutamate (Meloche, 1970) or histidine residues (Berghaüser et al. 1971).

With cysteine, bromopyruvate reacts in an anomalous way; $2 \mathrm{~mol}$ of acid are released $/ \mathrm{mol}$ of cysteine. In the presence of only $1 \mathrm{~mol} / \mathrm{mol}$ of bromopyruvate, only $55 \%$ of thiol groups react, although all the bromopyruvate is consumed. The product, with excess of bromopyruvate, migrates towards the anode on electrophoresis at $\mathrm{pH6.0}$ and does not give a ninhydrin colour on paper. In contrast quantitative analysis gives the same ninhydrin colour intensity as cysteine. It contains no free thiol group. Mass spectrometry of the borohydride-reduced compound treated with diazomethane as described for $N$-acetylcysteine gave a highest mass peak with $m / e$ 217. Husain \& Lowe (1965) have reported that $N$-p-toluene-sulphonylglycine chloromethyl ketone reacts with cysteine to form a dihydrothiazole. The analogous reaction with bromopyruvate would give the thiazole (compound II). This would account for the observed properties of the product, including the mass-spectrum peak, since the molecular weight of the dimethyl ester is 217. However, it does not account for the apparent reaction with $2 \mathrm{~mol}$ of bromopyruvate. This might be explained by the reaction of the very reactive compound (II) with a further mol of bromopyruvate to give compound (III).
We thank the Science Research Council for support for part of this work.

\section{REFERENCES}

Andrews, P. (1965). Biochem. J. 96, 595.

Baker, J. P. \& Rabin, B. R. (1969). Eur. J. Biochem. 11, 154.

Barnett, J. E. G. (1967). Biochem. J. 105, 42 P.

Berghaüser, J., Falderbaum, I. \& Woenckhaus, C. (1971). Hoppe-Seyler's Z. physiol. Chem. 352, 52.

Brunetti, P., Jourdian, G. W. \& Roseman, S. (1962). J. biol. Chem. 237, 2447.

Brunetti, P., Swanson, A. \& Roseman, S. (1963). In Methods in Enzymology, vol. 6, p. 465. Ed. by Colowick, S. P. \& Kaplan, N. O. Now York: Academic Press Inc. Comb, D. G. \& Roseman, S. (1960). J. biol. Chem. 235, 2529.

Comb, D. G. \& Roseman, S. (1962). In Methods in Enzymology, vol. 5, p. 391. Ed. by Colowick, S. P. \& Kaplan, N. O. New York: Academic Press Inc.

Ellman, G. L. (1959). Archs Biochem. Biophys. 82, 70.

Howard, J. W. \& Fraser, W. A. (1961). In Organic Synthesis, collective vol. 1, p. 475 . Ed. by Gilman, H. \& Blatt, A. H. New York: J. Wiley and Sons Inc.

Husain, S. S. \& Lowe, G. (1965). Chem. Commun. p. 345. Ingram, J. M. \& Wood, W. A. (1965). J. biol. Chem. 240, 4146.

Lowry, O. H., Rosebrough, N. J., Farr, A. L. \& Randall, R. J. (1951). J. biol. Chem. 193, 265.

Meloche, H. P. (1967). Biochemistry, Easton, 6, 2273.

Meloche, H. P. (1970). Biochemistry, Easton, 9, 5050.

Moore, S. \& Stein, W. H. (1948). J. biol. Chem. 176, 367.

Morino, Y. \& Okamato, M. (1970). Biochem. biophys. Res. Commun. 40, 600.

Morse, D. E. \& Horecker, B. L. (1968). Adv. Enzymol. 31, 125.

Rashed, N. \& Rabin, B. R. (1968). Eur.J. Biochem. 5, 147. Roche, T. E. \& McFadden, B. A. (1969). Biochem. biophys. Res. Commun. 37, 239.

Rutter, W. J. (1964). Fedn Proc. Fedn Am. Socs exp. Biol. 23, 1248.

Sirbasku, D. A. \& Binkley, S. B. (1970). Biochim. biophys. Acta, 206, 479.

Staub, M. \& Denes, G. (1967). Biochim. biophys. Acta, $139,519$.

Zalkin, H. \& Kling, D. (1968). Biochemistry, Easton, 7, 3566. 